\title{
THE IMPACT OF ONLINE LEARNING ON TEACHER-STUDENT TRUST AT UNIVERSITY LEVEL DURING PANDEMIC 2020
}

\author{
Ammara Nasim Sahi \\ M.Phil. Scholar Department of Education, \\ Air University, Islamabad, Pakistan, \\ ammarairshad@gmail.com
}

\section{Tahira Bibi}

Lecturer, EPPSL Department, Faculty of Education, Allama Iqbal Open University Islamabad, Pakistan

Irshad Ali

M.Phil. Scholar Department of Governance and Public Policy, National Defense University, Islamabad

Pakistan

\begin{abstract}
Online learning is the only mean of teaching during the pandemic. This quantitative research covers causal-comparative aspects of changes in the trust level and explores the relationships between teachers and students during virtual learning at the university level. This study presents the findings, first in a descriptive manner, and then as an analytical tool, using the Community of Inquiry Framework (CoI) (Garrison, Anderson, and Archer 2000). The study's findings reveal a variety of factors and point to several indicators that can help teachers and students develop their relationships for greater success in online classrooms. On the one side pandemic hindered to go for survey physically but on the other side, it made it easy to get responses online through purposive sampling from 10 universities of the country using the Google form in limited time. Results of the study show that the trust level of students and teachers has decreased during online classes and it caused frustration, apprehensions and created a gap between students and teachers. Teachers need professional training to make online classes friendly and there should be some individual virtual meetings with students. Teachers need to be accessible on phone calls or zoom/skype/google at least during working hours.
\end{abstract}

Keywords: Trust, Students, Teachers, Online classes, Covid-19, University

\section{INTRODUCTION}

Due to the COVID-19, universities have moved to online learning solutions and teachers are scrambled to adjust the teaching learning process and techniques. During online classes the teacherstudent trust level is challenged and this research compares the trust level between teachers and students in online classes during COVID-19.

University students feel appeased to develop a relationship with teachers when they listen them carefully and are available to address their queries. University students not only want to express their matters with them but they have expectations to receive guidance from them also. Low level of trust usually causes bad impact on student teacher relationship. So, this research identified key factors of teacher-student trust level and helped to build the trust level between teachers and students during online learning.

Study analyzed the pandemic situation with special focus on how it has influenced the routine education practices. To do this, the research reviewed the literature around the effects of online learning. This helped in finding published sources to explore the challenges faced by students while conducting the online learning sessions. The research ultimately presents findings from the literature revealing impacts of online learning on the teacher student trust at university level.

\section{Research Objectives}

1. To identify the key factors of teacher-student trust at the University level. 
2. To investigate the effects of online teaching on the teacher-student trust at the university level during the pandemic.

3. To suggest the ways for improving trust level between university teachers and students with the impacts caused by the pandemic.

\section{Research Questions}

This research seeks to address the following research questions:

1. What are the challenges posed by the online learning, especially during COVID19?

2. How does it affect teacher-student trust?

3. What are the causes of change in the trust levels pertaining to the online classes especially at the University level?

\section{Research Hypothesis}

Ho: Online learning doesn't affect the trust level between the teachers and students at the university.

H1: Online learning affects the trust level between the teachers and students at the university level.

\section{LITERATURE REVIEW}

The level of trust between teachers and students during online classes in COVID19 was examined and assessed in this study. The findings are described in this paper, and the Community of Inquiry Framework (CoI) (Garrison, Anderson, and Archer 2000) is utilized as an analytical tool.

Anderson (2017) examines how the notion of the Community of Inquiry has evolved through time, as well as how it is used to teaching and learning in the digital age. The current CoI model's fundamental flaw is that it aids in the development of an effective teaching model. It looks into the level of trust between professors and students in the context of online learning activities. In reality, this study provides a critical review of the research literature on the impact of online learning on university-level teacher-student trust. As a result of the unexpected shutdown of face-to-face educational activities in reaction to the Covid 19 epidemic, teachers became aware of the differences between online teaching and their other modes of operation. Online teaching is a recognized type of working technique for many instructors (Goodyear et.al,2002).

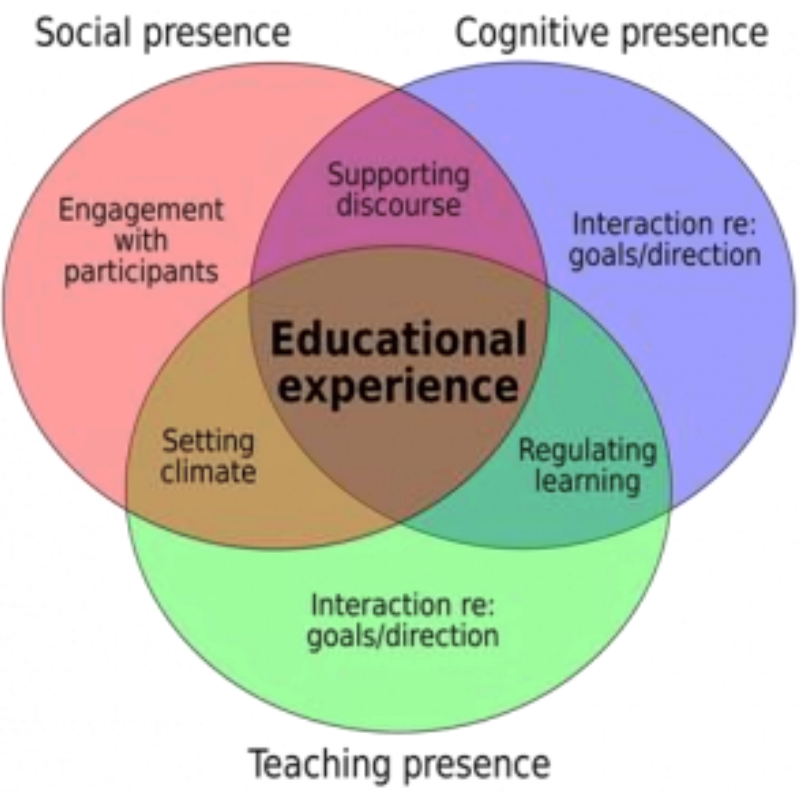

Figure 1. Teaching Presence

Teachers have been asked to become both designers and tutors almost overnight in the Covid19 emergency circumstance, employing tools that few have grasped fluently. This research throws some light on the pedagogical skills that new online teachers require in order to create meaningful learning activities and thrive in this unfamiliar environment.

It is necessary to do in-depth research on trust between lecturers and students, because trust can reduce risks and unpleasant possibilities in the learning process, as well as foster a positive learning climate (Durnford, 2010). Trust in the relationship between lecturers and students has been shown to accelerate academic achievement (Goddard, Tschannen-Moran, \& Hoy, 2001), as well as increase the positive climate in the classroom (Raider-Roth, 2005). Trust in the relationship between lecturers and students also shows a unique participation in the adjustment of learning, learning system, and various behavioral problems in institutions (Goddard, Tschannen-Moran, \& Hoy, 2001). 
The homebound student is expected to take an exam while seated in front of his or her laptop camera, with no access to books, notes, or a smartphone. As a result, the teacher is needed to keep a sharp check on numerous students using Zoom or steams at the same time. Neither of the hypotheses is true. The learner can copy the question and paste it into the laptop's Google search box or an unseen smartphone by moving slightly out of the camera's field of view, for example. The solution appears even before he/she finishes typing .As a result of COVID-19, in-person exam proctoring is no longer viable, and standard safeguards have vanished. My mailbox is overflowing with agitated emails from university students across Pakistan, bemoaning their classmates' use of unfair and unethical methods. When I combine these comments with those of my colleagues at various colleges, as well as my own online teaching experience, I get a horrifyingly depressing picture. P. 2020 ( Hoodbhoy )

Recent research in the field of trust appears to be more promising (Bryk \& Schneider, 2002; Smith, Hoy, \& Sweetland, 2001; Tschannen-Moran \& Hoy, 1999). Trust, defined as one party's willingness to be vulnerable to another in the belief that the latter is (a) courteous (b) reliable (c) competent, (d) honest, and (e) frank (Tschannen-Moran \& Hoy, 1999, p. 189), has been shown to have a significant impact on student outcomes such as academic performance.

The advent of parent choice programs such as vouchers, home schooling, and charter schools, as well as increased legislation and the use of high stakes testing, all point to a waning trust in public education as a major issue for educators. Furthermore, trust has major implications for all stakeholders in the context of schools and can be a valuable resource in establishing a prosperous school climate (Bryk \& Schneider, 2002; Tschannen-Moran \& Hoy, 1999).

\section{RESEARCH METHODOLOGY Research Design}

It is descriptive research exploring causal comparative aspects of changes in the trust level. A close ended questionnaire for teachers and students was developed separately on Google form. Online survey collected data using Google Forms.

\section{Research Population}

The study covered teaching faculty and Graduate, Masters and Postgraduates level students enrolled in the Universities. These respondents included the ones who are currently engaged in the online teaching as well as practiced the face-to-face learning.

\section{Research Sample}

The sample size was determined using a purposive sampling technique.

The sampling strata included at least 10 students and 2 teachers each from the following universities:

1. Air University of Islamabad,

2. Quaid Azam university, Islamabad

3. Sindh University Jamshoro,

4. Mehran University of Engineering and Technology, Jamshoro,

5. Shaheed Benazir Bhutto Women University, NawabShah,

6. Fast University (Lahore)Punjab,

7. Shaheed Benazir Bhutto Women University Peshawar, Khyber-Pakhtunkhwa,

8. University of Baluchistan,

9. Karakorum International University of Gilgit Baltistan and

10. University of Kotli Azad Jammu Kashmir)

Data collection and Analysis

Each study topic relating to the experiences of students attending online classes and the factors that affected those experiences was arranged around the data. This data was then entered into SPSS software to obtain correct results. Positive and negative feelings about online education were stated on a 5-point Likert scale in the responses. 


\section{Research Tools}

The instrument was built from the ground up using the CoI model. This is a closed-ended questionnaire with Likert five-point rating scales of Never (1 point), Rarely (2 points), Sometimes (3 points), Often (4 points), and Always (5 points) (5-points)

\section{Analysis}

The study is based on data collected through Google forms. The researcher utilized SPSS software to evaluate the data and identify certain values after collecting it. The transformed data are then used to make conclusions and put the hypothesis to the test.

\section{RESULTS AND DISCUSSION}

Each study topic relating to the experiences of students attending online classes and the factors that affected those experiences was arranged around the data. This data was then entered into SPSS software to obtain correct results. Positive and negative feelings about online education were stated on a 5-point Likert scale in the responses. The following research questions were answered as a result of data gathering and analysis: What problems does online learning provide, particularly during COVID19? What impact does it have on teacher-student trust? What are the reasons for the decline in trust in online education, particularly at the university level?

\section{Demographics}

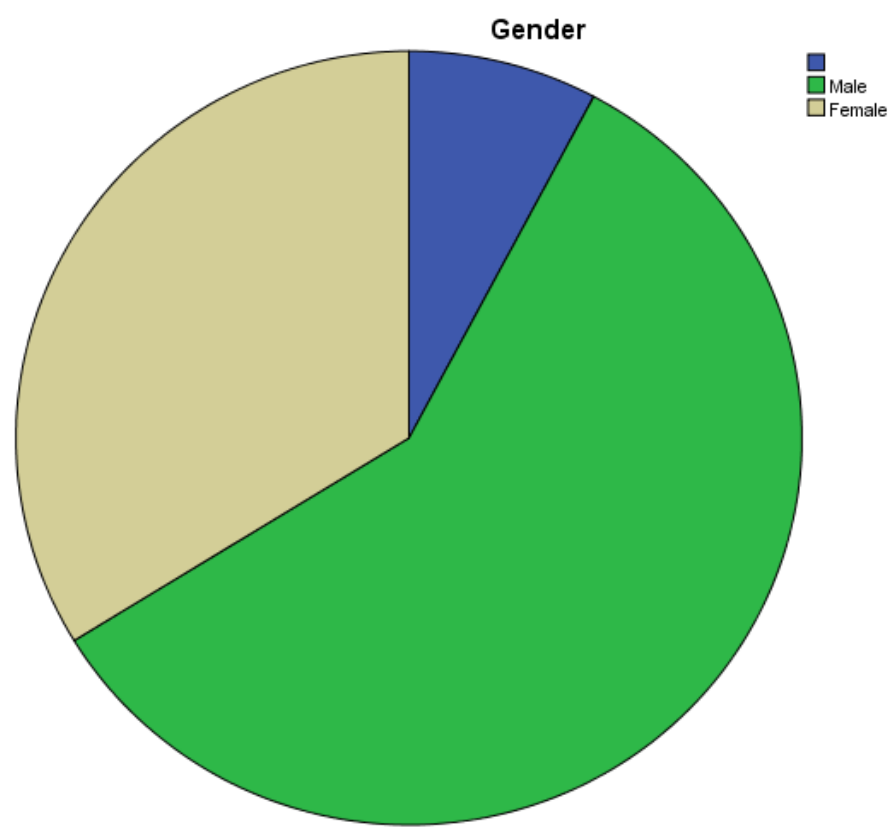

Figure 2 Pie graph

Figure 2 reveals that $58.4 \%$ male students responded on the other hand $33.8 \%$ female students responded and $7.8 \%$ didn't mention their gender. 


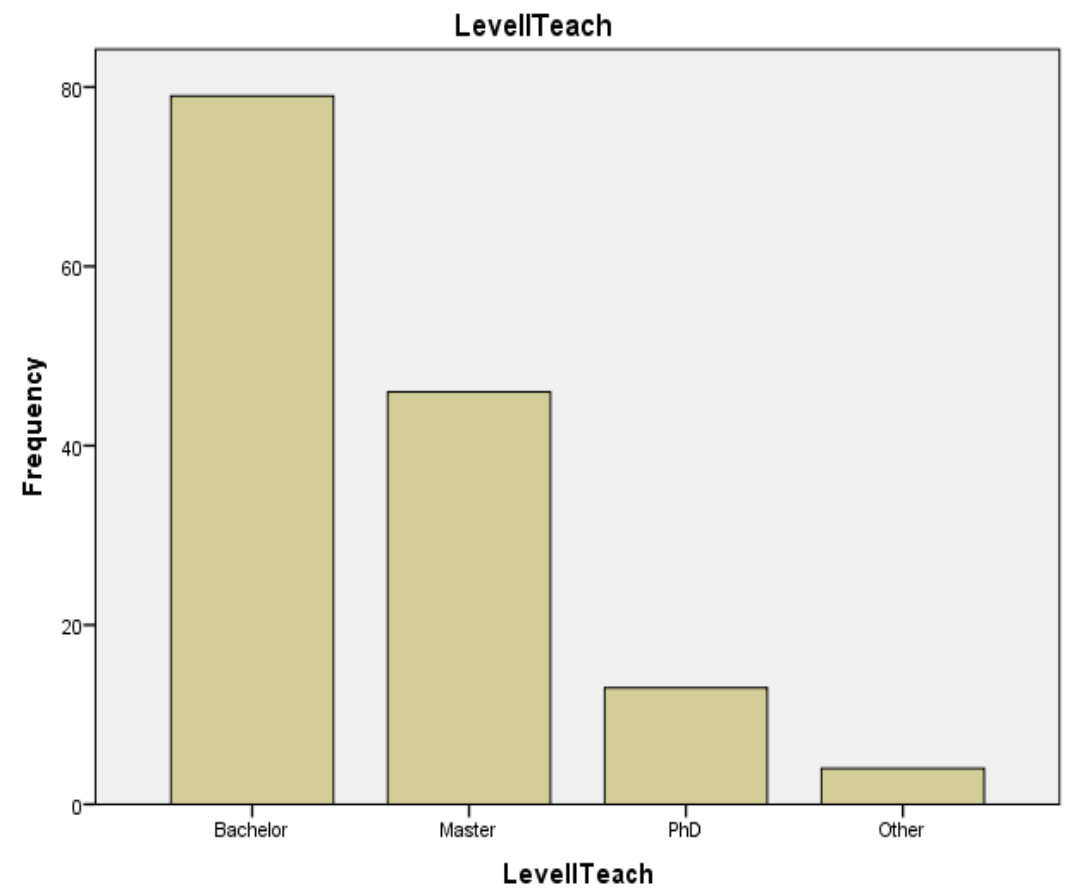

Figure 3 Bar Graph

Figure 3 reveals that $55.6 \%$ respondent students were from bachelor side,32.4\% from master, $9.2 \% \mathrm{PhD}$ and $2.8 \%$, were from other levels.

Table 1

Geographical representation of Respondents

\begin{tabular}{lllll}
\hline & & Frequency & Percent & Valid Percent \\
\hline & Islamabad & 48 & 31.2 & 33.8 \\
& Punjab & 26 & 16.9 & 18.3 \\
& Sindh & 37 & 24.0 & 26.1 \\
& Khyber Pakhtunkhwa & 8 & 5.2 & 5.6 \\
Valid & Baluchistan & 7 & 4.5 & 4.9 \\
& Gilgit Baltistan & 9 & 5.8 & 6.3 \\
& Azad Jammu Kashmir & 7 & 4.5 & 4.9 \\
& Total & 142 & 92.2 & 100.0 \\
Missing & System & & & \\
\hline Total & & 154 & 100.0 & \\
\hline
\end{tabular}

Table 1 identify the geographical representation of the respondents of the study that $33.8 \%$ from Islamabad,18.3\% from Punjab,26.1\% from Sindh,5.6\% from Khyber Pakhtunkhwa,4.9\% from Baluchistan,6.3\% from Gilgit Baltistan and 4.9\% from Azad Jammu Kashmir and it is observed that most of the respondents are from Islamabad. 
Table 2

Finishing and turning in assignments face to face mode

\begin{tabular}{rlrrr}
\hline & & Prequency & Percent & Valid Percent \\
\hline \multirow{4}{*}{ Valid } & Never & 11 & 7.1 & 7.8 \\
& Rarely & 18 & 11.7 & 12.8 \\
& Sometimes & 33 & 21.4 & 23.4 \\
& Often & 57 & 37.0 & 40.4 \\
& Always & 22 & 14.3 & 15.6 \\
& Total & 141 & 91.6 & 100.0 \\
\hline Total & & 154 & 100.0 & \\
\hline
\end{tabular}

In the light of the values derived from collected data from students it is observed that for $15.6 \%$ students finishing and turning in assignments is always stressful for $40.4 \%$ is often stressful, for $23.4 \%$ students it is sometimes stressful, for $12.8 \%$ is rarely stressful but for $7.8 \%$ finishing and turning in assignments is never stressful during face-to-face classes.

Table 3

Finishing and turning in assignments in online mode

\begin{tabular}{|c|c|c|c|c|}
\hline & & Frequency & Percent & Valid Percent \\
\hline \multirow{6}{*}{ Valid } & Never & 18 & 11.7 & 12.7 \\
\hline & Rarely & 33 & 21.4 & 23.2 \\
\hline & Sometimes & 33 & 21.4 & 23.2 \\
\hline & Often & 36 & 23.4 & 25.4 \\
\hline & Always & 22 & 14.3 & 15.5 \\
\hline & Total & 142 & 92.2 & 100.0 \\
\hline Total & & 154 & 100.0 & \\
\hline
\end{tabular}

Table 3 reveals that $15.5 \%$ students opined that finishing and turning in assignments is always stressful during online classes and $25.4 \%$ expressed it is often stressful, in view of $23.2 \%$ it is sometimes stressful, for $23.2 \%$ is rarely stressful and 12.7 expressed that finishing and turning in assignments is never stressful during online classes.

Table 4

Teachers' behavior towards students' issues face to face mode

\begin{tabular}{lllll}
\hline & & Frequency & Percent & Valid Percent \\
\hline & Never & 1 & .6 & .7 \\
& Rarely & 9 & 5.8 & 6.3 \\
Valid & Sometimes & 46 & 29.9 & 32.4 \\
& Often & 60 & 39.0 & 42.3 \\
& Always & 26 & 16.9 & 18.3 \\
& Total & 142 & 92.2 & 100.0 \\
\hline Total & & 154 & 100.0 & \\
\hline
\end{tabular}

Table 4 identify that $18 \%$ Teachers always listen the students' issues empathetically during fac to face classes. 42.3Teachers often listen the students' issues empathetically during fac to face classes. 32.4Teachers sometimes listen the students' issues empathetically during fac to face classes.6.3 Teachers rarely listen the students' issues empathetically during fac to face classes. 0.7 Teachers never listen the students' issues empathetically during face to face classes. 
Table 5

Teachers' behavior towards students' issues online mode

\begin{tabular}{rlrrr}
\hline & \multicolumn{2}{c}{ Prequency } & \multicolumn{2}{c}{ Valid Percent } \\
\hline \multirow{4}{*}{ Valid } & Never & 37 & 24.0 & 26.1 \\
& Rarely & 56 & 36.4 & 39.4 \\
& Sometimes & 33 & 21.4 & 23.2 \\
& Often & 12 & 7.8 & 8.5 \\
& Always & 4 & 2.6 & 2.8 \\
& Total & 142 & 92.2 & 100.0 \\
\hline Total & & 154 & 100.0 & \\
\hline
\end{tabular}

Table 5 identify that $26 \%$ Teachers never listen the students' issues empathetically during online classes.39.4 Teachers rarely listen the students' issues empathetically during online classes. 23.2Teachers sometimes listen the students' issues empathetically during online classes.8.5 Teachers often listen the students' issues empathetically during online classes. 2.8Teachers always listen the students' issues empathetically during online classes.

Table 6

Teachers Directions face to face mode

\begin{tabular}{rlrrr}
\hline & Frequency & Percent & Valid Percent \\
\hline \multirow{4}{*}{ Valid } & 1 & .6 & .7 \\
& Never & 10 & 6.5 & 7.0 \\
& Rarely & 38 & 24.7 & 26.8 \\
& Sometimes & 58 & 37.7 & 40.8 \\
& Often & 35 & 22.7 & 24.6 \\
& Always & 142 & 92.2 & 100.0 \\
\hline Total & Total & 154 & 100.0 & \\
\hline
\end{tabular}

Table 6 identify that $25 \%$ teachers always give clear directions during face-to-face classes. 40.8Teachers often give clear directions during face-to-face classes.26.8 Teachers sometimes give clear directions during face-to-face classes. 26.8Teachers rarely give clear directions during face-toface classes. 0.7 Teachers never give clear directions during face-to-face classes.

Table 7

Teachers Directions online mode

\begin{tabular}{|c|c|c|c|c|}
\hline & & Frequency & Percent & Valid Percent \\
\hline \multirow{6}{*}{ Valid } & Never & 36 & 23.4 & 25.4 \\
\hline & Rarely & 51 & 33.1 & 35.9 \\
\hline & Sometimes & 32 & 20.8 & 22.5 \\
\hline & Often & 13 & 8.4 & 9.2 \\
\hline & Always & 10 & 6.5 & 7.0 \\
\hline & Total & 142 & 92.2 & 100.0 \\
\hline Total & & 154 & 100.0 & \\
\hline
\end{tabular}

Table 7 indicates that 25.4 teachers never give clear directions during classes during online classes. $35.9 \mathrm{My}$ teachers rarely give clear directions during classes during online classes. 22.5 teachers sometimes give clear directions during classes during online classes.9.2 teachers often give clear directions during classes during online classes. $7.0 \mathrm{My}$ teachers always give clear directions during classes during online classes. 
Table 8

Teachers' activities in class during face to face mode

\begin{tabular}{rlrrr}
\hline & & Frequency & Percent & Valid Percent \\
\hline \multirow{4}{*}{ Valid } & 1 & .6 & .7 \\
& Never & 5 & 3.2 & 3.5 \\
& Rarely & 40 & 26.0 & 28.2 \\
& Sometimes & 56 & 36.4 & 39.4 \\
& Often & 40 & 26.0 & 28.2 \\
& Always & 142 & 92.2 & 100.0 \\
\hline Total & Total & 154 & 100.0 & \\
\hline
\end{tabular}

Data presented in the table 8 indicate that teachers typically undertake content-related activities during face-to-face classes, according to 39.4 percent of respondents. 28.2 percent During face-to-face classrooms, teachers occasionally undertake content-related activities. Teachers always undertake activities relevant to the material during face-to-face classes, according to 28.2 percent of students. 3.5 percent of respondents believe that during face-to-face classes, teachers rarely conduct activities related to the material. 7 percent of respondents believe that during face-to-face classes, teachers never do activities related to the material.

Table 9

Teachers' activities in class during online mode

\begin{tabular}{|c|c|c|c|c|}
\hline & & Frequency & Percent & Valid Percent \\
\hline \multirow{6}{*}{ Valid } & Never & 40 & 26.0 & 28.2 \\
\hline & Rarely & 40 & 26.0 & 28.2 \\
\hline & Sometimes & 40 & 26.0 & 28.2 \\
\hline & Often & 14 & 9.1 & 9.9 \\
\hline & Always & 8 & 5.2 & 5.6 \\
\hline & Total & 142 & 92.2 & 100.0 \\
\hline Total & & 154 & 100.0 & \\
\hline
\end{tabular}

Table 9 indicates that during online classes, 28.2 percent believe that teachers never undertake activities that are relevant to the topic. During online classrooms, 28.2 percent of teachers rarely conduct activities that are related to the subject. Teachers sometimes undertake activities relevant to the material during online classes, according to 28.2 percent of students. During online classrooms, $9.9 \%$ of teachers frequently do content-related activities, while 5.6 percent of teachers frequently conduct content-related activities.

Table 10

Teaching methods and face to face mode

\begin{tabular}{rlrrr}
\hline & Frequency & Percent & Valid Percent \\
\hline \multirow{4}{*}{ Valid } & Never & 1 & .6 & .7 \\
& Rarely & 12 & 7.8 & 8.5 \\
& Sometimes & 32 & 20.8 & 22.5 \\
& Often & 60 & 39.0 & 42.3 \\
& Always & 37 & 24.0 & 26.1 \\
& Total & 142 & 92.2 & 100.0 \\
\hline Total & & 154 & 100.0 & \\
\hline
\end{tabular}

Table 10 reveals that 26.1 percentage point During face-to-face classes, teachers' teaching methods are always constant. 42.3 During face-to-face classrooms, teachers' teaching methods are frequently constant. 22.5In face-to-face classes, teachers' teaching methods are not always constant. 8.5 In face-to-face classes, teachers' teaching methods are rarely constant. 7 percentage points During face-to-face classes, teachers' teaching methods are seldom consistent. 
Table 11

Teaching methods and face to face mode

\begin{tabular}{|c|c|c|c|c|}
\hline & & Frequency & Percent & Valid Percent \\
\hline \multirow{6}{*}{ Valid } & Never & 38 & 24.7 & 26.8 \\
\hline & Rarely & 41 & 26.6 & 28.9 \\
\hline & Sometimes & 39 & 25.3 & 27.5 \\
\hline & Often & 16 & 10.4 & 11.3 \\
\hline & Always & 8 & 5.2 & 5.6 \\
\hline & Total & 142 & 92.2 & 100.0 \\
\hline Total & & 154 & 100.0 & \\
\hline
\end{tabular}

Table 11 reveals that teachers' teaching approaches are always consistent for 5.6 percent of students, are frequently consistent for 11.3 percent of students, and are occasionally consistent for 27.5 percent of students during online sessions. Teachers' teaching methods are rarely constant, according to $28.9 \%$ of pupils, while teachers' teaching methods are never consistent, according to $26.8 \%$. Meanwhile, $29.8 \%$ said their instructors always manage time well in class during face-to-face classes, 38.3\% said teachers frequently manage time well, 26.2 percent said their teachers occasionally manage time well, and 5.0 percent said their teachers seldom manage time in class during face-to-face classes. $7 \%$ exclaimed the teachers never manage time well in class during face-toface classes.

Teachers always manage time well in class during online classes, according to 2.8 percent of students, 5.6 percent said that teachers often manage time well in class during online classes, but 29.6 percent said that teachers sometimes manage time well, 28.2 percent said that teachers rarely manage time well, and 33.8 percent said that teachers never manage time well in class during online classes.

$29.6 \%$ During face-to-face classes, learning is always interesting. 38.7\% Learning is frequently engaging in face-to-face classes. 26.1 percent Learning in face-to-face classes can be interesting at times. 1.4 percent In face-to-face classes, learning is rarely exciting. $1.4 \%$ Learning is rarely interesting during face-to-face classes. $4.2 \%$ Learning is never interesting during face-to-face classes.

27.7\% responded that online classes are never fascinating when it comes to learning. 31.9 percent opined the online classes are rarely exciting when it comes to learning. For 23.4 percent During online classes, learning can be interesting at times, for 11.3 percent Online lessons are typically interesting to learn in and 5.7 percent expressed the online classes are always enjoyable to learn in.2.1\% supported that teacher never criticize the students during face-to-face classes. $4.2 \mathrm{~T} \%$ exclaimed the teachers rarely criticize the students during face-to-face classes. For $20.4 \%$ teachers sometimes criticize the students during face-to-face classes, for $39.4 \%$ Teachers often criticize the students during face-to-face classes, for 33.8\% Teachers always criticize the students during face-toface classes. $2.1 \%$ expressed the teachers always criticize the students during online classes, $6.3 \%$ say that teachers often criticize the students during online classes and $26.8 \%$ opined those teachers sometimes criticize the students during online classes. For $41.5 \%$ teachers often criticize the students during online classes and for $23.2 \%$ teachers always criticize the students during online classes.

$28.2 \%$ informed that teachers always treat the students equally during face-to-face classes. $45.1 \%$ told teachers often treat the students equally during face-to-face classes and $16.9 \%$ said the Teachers sometimes treat the students equally during face-to-face classes and for $4.2 \%$ teachers rarely treat the students equally during face-to-face classes. 5.6\% expressed the teachers never treat the students equally during face-to-face classes and for $25.4 \%$ teachers never treat the students equally during online classes. Meanwhile $33.8 \%$ responded that teachers rarely treat the students equally during online classes, $28.9 \%$ raised the teachers sometimes treat the students equally during online classes. 9.2\% directed the teachers often treat the students equally during online classes and for $2.8 \%$ Teachers always treat the students equally during online classes.

$28.9 \%$ teachers are always available to solve students' issues during face-to-face classes. 42.3\% teachers are often available to solve students' issues during face-to-face classes. 19.7\% Teachers are sometimes available to solve students' issues during face-to-face classes.4.9 $\%$ Teachers are often available to solve students' issues during face-to-face classes. $4.1 \%$ Teachers are always available to solve students' issues during face-to-face classes. 
$38.0 \%$ teachers are never available to solve students' issues during online classes. 40.8 Teachers are rarely available to solve students' issues during online classes.14.8 Teachers are sometimes available to solve students' issues during online classes. 2.8Teachers are often available to solve students' issues during online classes. 3.5Teachers are always available to solve students' issues during online classes. 26.8\% Teachers are always hasty to complete lesson during face-to-face classes.45.8 \% Teachers are often hasty to complete lesson during face-to-face classes. $21.1 \%$ Teachers are sometimes hasty to complete lesson during face-to-face classes. 3.5\% Teachers are rarely hasty to complete lesson during face-to-face classes.2.8 \% Teachers are never hasty to complete lesson during face-to-face classes.

28.9\% Teachers are never hasty to complete lesson during online classes. 38.0\%Teachers are rarely hasty to complete lesson during online classes.20.4\% Teachers are sometimes hasty to complete lesson during online classes. 5.6\% Teachers are often hasty to complete lesson during online classes.7.0\% Teachers are always hasty to complete lesson during online classes. 28.9It's always easy to access and talk to teachers separately for discussing any issue during face-to-face classes.49.3 It's often easy to access and talk to teachers separately for discussing any issue during face-to-face classes. 16.9It's sometimes easy to access and talk to teachers separately for discussing any issue during face-to-face classes.2.1 It's rarely easy to access and talk to teachers separately for discussing any issue during face-to-face classes.2.8 It's never easy to access and talk to teachers separately for discussing any issue during face-to-face classes.

While responding to a question on easy access and talk to teacher, $29.6 \%$ informed it is never easy, $38.0 \%$ it's rarely easy, $21.8 \%$ it's sometimes easy, $6.3 \%$ it's often easy and $4.2 \%$ said it's always easy to access and talk to teachers separately for discussing any issue during online classes. Students (26.8\%) shared teachers are always focused on the syllabus during face-to-face classes, $49.3 \%$ said teachers are often focused, $19.0 \%$ said teachers are sometimes focused while 3.5\% teachers are rarely focused, and $1.4 \%$ shared teachers are never focused on the syllabus during face-to-face classes. On the hand, $26.1 \%$ said teachers are never focused on the syllabus during online classes, $40.1 \%$ shared teachers are rarely focused, $22.5 \%$ shared teachers are sometimes focused, $6.3 \%$ shared teachers are often focused, and $4.9 \%$ said teachers are always focused on the syllabus during online classes.

The research asked if students find it easy to ask a question during the class. Total of $33.8 \%$ students opine that it is always easy to ask questions from teacher during face-to-face classes, $38.0 \%$ said it is often easy, $21.1 \%$ said sometimes easy, for $3.5 \%$ it is rarely easy, for equal $3.5 \%$ it is never easy to ask questions from teacher during face-to-face classes. On the other hand, $30.5 \%$ students mark that it is never easy to ask questions from teacher during online classes as well. For $33.3 \%$ it is rarely easy, for $25.5 \%$ it is sometimes easy, for $8.5 \%$ it is easy, and for $2.1 \%$ it is always is easy to ask questions from teacher during online classes.

Students were also asked about their participation in the online and face to face classes. Responding to face to face question, $30.3 \%$ said teachers never encourage them to participate actively during face-to-face classes, $42.3 \%$ said teachers rarely encourage, $22.5 \%$ said teachers sometimes encourage to participate actively, $2.8 \%$ said teachers often encourage participate actively, while only $2.1 \%$ said teachers always encourage them us to participate actively during face-to-face classes. For the online classes, $30.3 \%$ students shared that teacher never encourage them to participate actively during the online classes, $42.3 \%$ opine that teacher rarely encourage, $22.5 \%$ students expressed that teacher sometimes encourage, $2.8 \%$ showed that teachers often encourage, and only $2.1 \%$ say teachers always encourage them to participate actively during online classes.

The purpose of this study was to look into students' perception for online education based on their own online learning experiences. The aspects that affected those students' online learning experiences were also looked into. The outcomes of this study are divided into two categories: good and negative experiences of students. Flexibility, cost-effectiveness, electronic research availability, and ease of connection to the Internet were all beneficial experiences for the students. Students' bad experiences included delayed feedback from teachers, unavailable technical support from instructors, a lack of self-control and motivation, and a sense of isolation.

Students' positive experiences were aided by the flexibility of class participation time and self-paced study, as well as the cost-effectiveness of online classes, electronic research availability, well-designed course layout, ease of Internet connection, easy navigation of the online class interface, 
and familiarity with the instructor. Delay in receiving feedback from the instructor; lack of technical help; lack of self-regulation and self-motivation; feeling of isolation; boring instructional methods; and poorly-designed course content were all factors that contributed to students' bad experiences.

Meanwhile collected data and analyzed values from students show that, turning assignments is not very much stressful for students and there may be different reasons behind, like students have opportunity to collect material from online resources easily and it saves the time. In this regard this is positive impact of online classes and so for trust level between teachers and students.

Data shows that there is a negative feeling from learners that teachers don't listen them empathetically and this decreases the trust level. They feel unheard. Respondents are dissatisfied with the directions given by teachers during online classes. They may feel difficulty to understand learning material or may not be able to follow teachers' instructions properly, so they feel gape to go in clear direction and this void can causes mistrust. Learners opine that teacher don't conduct relevant activities so students can't clear their concepts which decrease the level of trust between teachers and students. Teachers teaching methods are not consistent so it creates hue and cry from learners and decreases the trust level.

Learners at university level express their feelings via google form that Teachers don't manage time well and it is also a cause to not have a healthy trust level between teachers and students so they don't perceive that learning is interesting during online classes.41.5\% learners are in this view that Teachers often criticize the students during online classes and it is the major cause to decrease trust level between teachers and students.45.1\% students say that teachers often treat the students equally during face-to-face classes but during online classes teachers discriminate among students.45.8\% learners opine that teacher are often hasty to complete lesson during face-to-face classes but online classes are prolonged and it may decrease interest of learner and effects on trust level between teachers and students.

Data shows that to access and talk to teachers separately for discussion of any matter is not easy and looks big challenge. It decreases the trust level between teacher and learner. Collected data shows that Teachers are not focused on the syllabus in due time so take extra classes on weekends and it halts the freedom of learner and may decrease trust level between teachers and students. Responses show that it is never easy to ask questions from teachers during online classes and it hinders effective learning and may decrease trust level between teachers and students. Responses on Likert scale show that most of the times teachers don't encourage learners to participate actively and it demotivates and may affects trust level between them.

Kelley (2008) narrates that usually it observed the students take their guidelines and impression from the instructor, and when the instructor is not there, the students will be misled. But if the instructor is positive from the beginning, showing emotions towards the students and the content, students will respond in the same way but in the phase of data collection $40.8 \%$ students responded that Teachers are not always available to solve students' issues during online classes and it creates mistrust between teachers and students.

\section{CONCLUSION AND RECOMMENDATIONS}

Online classes are the need of time when SARS-CoV-2 has plunged the world and doors of schools are shut. Teachers and learners both have a new experience of online learning so this immature teaching learning process creates apprehensions and one of those apprehensions is trust level. Research shows that students have anxiety during online classes. Students at university level face challenges to grasp the learning material and it halts the performance and ability of understanding. Research shows that trust level between teachers and students is badly hurt and decreased during COVID-19 so in the light of the results there are some recommendations below:

1. Teachers need immediate effective teachers training for proficiency and to make online learning productive and unharmed psychologically.

2. Teachers should be aware of students' mental condition which is already facing fear and anxiety of pandemic.

3. Teachers must go on virtual tours for appease of students.

4. Teachers should have extra sessions with students on hangout, WhatsApp, skype, zoom, Facebook messenger etc. 
5. Teachers must take feedback frequently without any identity of learner.

6. During online classes activities conducted by teachers must be user-friendly.

7. Instructions for students must not be ambiguous. Instructions of instructor need clarity.

8. To enhance the trust between teachers and students there is the need to listen students concern empathetically so the teaching learning process could be made effective and constructive.

\section{REFERENCES}

Abdullah, F., \& Ward, R. (2016). Developing a General Extended Technology Acceptance Model for E-Learning (GETAMEL) by analysing commonly used external factors. Computers in human behavior, 56, 238-256.

Androgenic, M. (2007) Espy: Surveillance and Power in the Interactive Era. Lawrence: University Press of Kansas, Print.

Ali, W. (2020). Online and remote learning in higher education institutes: A necessity in light of COVID-19 pandemic. Higher education studies, 10(3), 16-25.

Buber, M. (2003). Between man and man. Routledge.

Bryk, A., \& Schneider, B. (2002). Trust in schools: A core resource for improvement. Russell Sage Foundation.

Dawson, S., Burnett, B., \& McArdle, F. (2005, October). Watching learning from behind closed doors: The impact of surveillance on student online behaviour. In E-Learn: World Conference on E-Learning in Corporate, Government, Healthcare, and Higher Education (pp. 19781985). Association for the Advancement of Computing in Education (AACE).

Durnford, V. L. (2010). An examination of teacher-student trust in middle school classrooms. University of Massachusetts Amherst.

Garrison, D. R., Anderson, T., \& Archer, W. (2010). The first decade of the community of inquiry framework: A retrospective. The internet and higher education, 13(1-2), 5-9.

Goddard, R. D., Tschannen-Moran, M., \& Hoy, W. K. (2001). A multilevel examination of the distribution and effects of teacher trust in students and parents in urban elementary schools. The elementary school journal, 102(1), 3-17.

Gourlay, L., \& Stevenson, J. (2017). Teaching excellence in higher education: Critical perspectives.

Hai-Jew, S. (2006). Operationalizing trust: Building the online trust student survey (OTSS). Journal of Interactive Instruction Development, 19(2), 16-30

Hoodbhoy, P. (2020). Pakistan's Higher Education System: History, Status, Assessment. Handbook of Education Systems in South Asia, 1-32.

Kelly, R., \& Silverman, D. (2008). Teaching to the learning styles across generations. Faculty Focus.

Meldrum, R. J. (2001). Power relations in peer-and self-assessment (Doctoral dissertation, University of Auckland).

Raider-Roth, M. B. (2005). Trusting what you know: The high stakes of classroom relationships. Jossey-Bass.

Steeples, C., Jones, C., \& Goodyear, P. (2002). Beyond e-learning: A future for networked learning. In Networked learning: Perspectives and issues (pp. 323-341). Springer, London.

Tschannen-Moran \& Hoy, 1999).

Wang, Y. D. (2014). Building student trust in online learning environments. Distance Education, 35(3), 345-359.

Zhang, W., Wang, Y., Yang, L., \& Wang, C. (2020). Suspending classes without stopping learning: China's education emergency management policy in the COVID-19 outbreak. 